\title{
Stochastic Food Deprivation Increases Cellular Immunity in Kunming Mice
}

\author{
Deli Xu1 ${ }^{*}$, Yufen Tian1, Ruisheng Li², Haotian Li1, Xiaonan Sun1, Qingbin Wang1, Jing Shi1, \\ Ping Zhou' ${ }^{1}$ Xiaolei Sun ${ }^{1}$ \\ ${ }^{1}$ Qufu Normal University, Qufu, China \\ ${ }^{2}$ Research and Technology Service Center, 302 Hospital of PLA, Beijing, China \\ Email: ${ }^{*}$ udl1975@163.com
}

Received 18 March 2014; revised 24 April 2014; accepted 1 May 2014

Copyright (C) 2014 by authors and Scientific Research Publishing Inc.

This work is licensed under the Creative Commons Attribution International License (CC BY). http://creativecommons.org/licenses/by/4.0/

(c) (i) Open Access

\begin{abstract}
Animals' immunity is an important factor to determine their survival and fitness. Unpredictable food shortage is common to small mammals due to fluctuation of food resources throughout a year. In general, acute food deprivation (FD) inhibited immune function in rodents. In the present study we tested the hypothesis that stochastic FD would also suppress $T$ cell-mediated immunity in mice. Fifteen adult male Kunming mice were randomly assigned into the Fed $(n=7)$ and FD $(n=8)$ groups, in which the latter were subjected to stochastic FD regime. Unexpectedly, T cell-mediated immunity assessed by PHA response was increased in the FD mice compared with the fed controls. However, body fat mass, wet thymus and spleen mass, white blood cells, serum leptin and corticosterone concentrations did not differ between the Fed and FD groups. Taken together, stochastic food deprivation can enhance cellular immunity in Kunming mice.
\end{abstract}

\section{Keywords}

Corticosterone, Leptin, Kunming Mice, Phytohaemagglutinin Response, Stochastic Food Deprivation

\section{Introduction}

Animals' immunity provides an important shelter against attack of pathogens in the environment and hence plays a crucial role in their survival and their fitness [1] [2]. Small mammals often face periods of unpredictable food shortage due to the fluctuation of food resources throughout a year [3] [4]. Many factors such as food quantity and quality exert significant influence on immune function for animals [5]-[8].

\footnotetext{
${ }^{*}$ Corresponding author.
} 
Some researchers have investigated the influences of food shortage on immune function, yet they have disparate results. For instance, Lord et al. [9] demonstrated that food deprivation for 2 days suppressed T-cell immune response in C57BL/6 mice. Similarly, delayed type hypersensitivity (DTH) indicative of T-cell immune response decreased in starved rats or ICR mice compared to the fed controls [10]-[12], and food deprivation for 2 days could also increase susceptibility to endotoxic shock in starved mice [13]. Kohno et al. [14] showed that intermittent starvation for 7 days had suppressive effect on DTH in NC/Nga mice. We have also found that 3-day starvation suppressed T-cell mediated immunity in wild Mongolian gerbils (Meriones unguiculatus) [15]. However, other investigators have reported different results. Mice starved for 2 or 3 days showed more resistance to the intracellular pathogen Listeria monocytogenes [16]. A short period of starvation also enhanced phagocytic activity of macrophages [17] and blood monocyte bactericidal activity [18] in mice. Similarly, shortterm repeated starvation has the potential to accelerate skin wound healing indicative of innate immunity [19]. Sogawa and Kubo [20] did not find any significant differences in immune function between the starved and control groups after short-term repeated fasting. Therefore, further research is required to clarify these inconsistent results in more mice strains or species.

Phytohaemagglutinin (PHA) response involves a subcutaneous injection of PHA that induces local T-cell stimulation and proliferation resulting in swelling [21]. It has been a tool for assessing mammalian T-cell immunity [22]. Additionally, immune organs such as thymus and spleen are indirect immunological parameters [23] [24]. Total white blood cells (or leukocytes, WBC) are also used to assess the overall health [6] [25].

Leptin is a cytokine-like peptide hormone synthesized and secreted mainly by adipose tissue [26]-[28]. Besides its regulatory role in energy homeostasis, it also plays an important role in immunity [29] [30]. Circulating leptin is positively correlated with adipose tissues, which are no longer considered as simply passive energy depots, but have been recently regarded as important endocrine and immune organs [31] [32]. Contrary to leptin which decreased during food deprivation, glucocorticoids such as corticosterone increased [15] [33], and these stress hormones generally have suppressive effect on immune function [34]. To date, however, we still have no idea about how immune function responds to stochastic food shortage in rodents. In the present study, we tested the hypothesis that stochastic food deprivation would suppress T cell-mediated immune response in Kunming mice.

\section{Materials and Methods}

\subsection{Animals and Experimental Design}

All animal procedures were licensed under the Institutional Animal Care and Use Committee of Qufu Normal University. Adult male Kunming mice (age: 6 months) used in this study were obtained from the Experiment Animal Center in Jining Medical College of Shangdong province. The animals were housed individually in plastic cages $(30 \mathrm{~cm} \times 15 \mathrm{~cm} \times 20 \mathrm{~cm}$ ) with sawdust as bedding under a constant photoperiod of $12 \mathrm{~L}: 12 \mathrm{D}(12 \mathrm{h:12}$ h light-dark cycle) and temperature of $23^{\circ} \mathrm{C} \pm 2^{\circ} \mathrm{C}$. Standard rat pellets chow (Animal Breeding Center in Jining Medical College, Jining, China) and water were provided ad libitum. After body mass stabilized, 15 male Kunming mice were selected and were randomly divided into and fed ad libitum (Fed) group $(\mathrm{n}=7)$ and stochastic food deprivation (FD) group $(n=8)$ in which each mouse was deprived of food for a random 3 days each week and fed ad libitum on the other 4 days. Day 0 and day n represented initial day and n days of treatment, respectively. Food deprivation occurred on day $1,3,5,8,10,13,16,18,21$. The course of treatment was 21 days.

\subsection{Cellular Immunity Assays}

PHA response was measured as described previously [15] [22]. Specifically, on day 19 we measured the footpad thickness of the left hind foot of the mice in the Fed and FD groups with a micrometer (Digimatic Indicator ID-C Mitutoyo Absolute cod. 547-301, Japan) to $\pm 0.01 \mathrm{~mm}$. Immediately thereafter, mice in both groups were injected subcutaneously $0.1 \mathrm{mg}$ of PHA (PHA-P, Sigma L-8754) dissolved in $0.03 \mathrm{~mL}$ of sterile saline (pH 7.4) in the middle of the footpad. After $6 \mathrm{~h}, 24 \mathrm{~h}$ and $48 \mathrm{~h}$ injection, we measured footpad thickness, respectively. The PHA response (i.e. cellular immunity) was calculated as the difference between pre- and post-injection measurements divided by initial footpad thickness $($ PHA response $=($ post PHA - pre PHA $) /$ pre PHA $)$. Six measures of footpad thickness were taken to obtain the value of each mouse [15] [22]. Only the $6 \mathrm{~h}$ data were included in the results because they were representative of the maximal response. 


\subsection{Body Composition}

Body composition was measured as described previously [15]. In brief, the visceral organs, including heart, thymus, lungs, liver, spleen, kidneys, adrenal glands, testes, epididymis, seminal vesicals and the digestive organs with contents (i.e., stomach, small intestine, caecum and colon) were dissected and weighed ( $\pm 1 \mathrm{mg})$. The stomach, small intestine, caecum and colon were rinsed with saline to eliminate all the gut contents, before being weighed. Moreover, subcutaneous fat, perirenal fat, perigonadal fat and mesenteric fat were also dissected carefully and weighted. All the four parts of fat mass was regarded as total body fat mass. Subcutaneous fat content, perirenal fat content, perigonadal fat content and mesenteric fat content were calculated as their respective fat mass divided by final body mass.

\subsection{White Blood Cells Assays}

At the end of the experiment, after collecting trunk blood, $20 \mu \mathrm{L}$ whole blood was diluted immediately in 0.38 $\mathrm{mL}$ solution containing $1.5 \%$ glacial acetic acid, $1 \%$ crystal violet (Sigma) and the leukocytes were counted in an improved Neubauer chamber using microscope. The total number of WBC was determined by counting all leucocytes in the four corner large-squares of the Neubauer chamber, and multiplying the raw data by $5 \times 10^{7}$ to obtain the final values $\left(10^{9}\right.$ cells/L) [35].

\subsection{Serum Leptin Assays}

Serum leptin concentrations were determined by mouse leptin ELISA kit (Cat. No. XL-85K, Linco Research Inc., Missouri, USA). The range detected by this assay was $0.3-8 \mathrm{ng} / \mathrm{mL}$ when using a $10 \mu \mathrm{L}$ sample (see manufacturer's instructions for mouse leptin RIA kit). The detailed procedure followed the manufacturer's instructions of the mouse leptin ELISA kit.

\subsection{Serum Corticosterone Assays}

Serum corticosterone concentrations were determined by mouse corticosterone ELISA kit (Cat. No. HR083, RapidBio Lab. Calabasas, California, USA). The range detected by this assay was $8-150 \mathrm{ng} / \mathrm{mL}$ when using a 10 $\mu \mathrm{L}$ sample (see manufacturer's instructions for multi-species leptin RIA kit). The detailed procedure followed the manufacturer's instructions of the mouse corticosterone ELISA kit.

\subsection{Statistical Analysis}

Data were analyzed using SPSS 13.0 software (SPSS Inc., Chicago, IL, USA). Prior to all statistical analyses, data were examined for normality and homogeneity of variance, using Kolmogorov-Smirnov and Levene tests, respectively. The ratio values including PHA response, fat content were subjected to arcsine transformation. The changes of body mass in the Fed and FD groups during food restriction period were subjected to repeated measurement analysis. The differences of body mass between the Fed and FD groups were analyzed by independent-samples t-test. Group differences in wet organ mass with body mass as the covariate were analyzed by General Linear Model multivariate analysis followed by Bonferroni post hoc tests. Group differences in other parameters (body compositions, PHA response, WBC, leptin and corticosterone concentrations) were analyzed by independent-samples t-test. Pearson correlation analysis was performed to determine the correlations of PHA response with leptin and corticosterone in the Fed and FD groups. The correlation of serum leptin levels with total body fat mass was also calculated for all mice. Results were expressed as mean $\pm \mathrm{SE}$, and $\mathrm{P}<0.05$ was considered to be statistically significant.

\section{Results}

\subsection{Body Mass}

On day 0 , body mass between the Fed and FD groups was not different $(\mathrm{t}=0.010, \mathrm{df}=13, \mathrm{P}=0.992)$. On stochastic FD days (day $1: \mathrm{t}=2.964, \mathrm{df}=13, \mathrm{P}=0.011$; day $3: \mathrm{t}=3.192, \mathrm{df}=13, \mathrm{P}=0.007$; day 5 : $\mathrm{t}=3.224$, $\mathrm{df}=$ $13, \mathrm{P}=0.007$; day $8: \mathrm{t}=3.120$, $\mathrm{df}=13, \mathrm{P}=0.008$; day $10: \mathrm{t}=3.217$, $\mathrm{df}=13, \mathrm{P}=0.007$; day $13: \mathrm{t}=3.194$, $\mathrm{df}=$ $13, \mathrm{P}=0.007$; day 16: $\mathrm{t}=2.300, \mathrm{df}=13, \mathrm{P}=0.039$; day 18: $\mathrm{t}=2.671, \mathrm{df}=13, \mathrm{P}=0.019$; day 21: $\mathrm{t}=2.416, \mathrm{df}=$ $13, \mathrm{P}=0.031$ ), body mass in the FD group was significantly lower than that of the fed controls (Figure 1). 


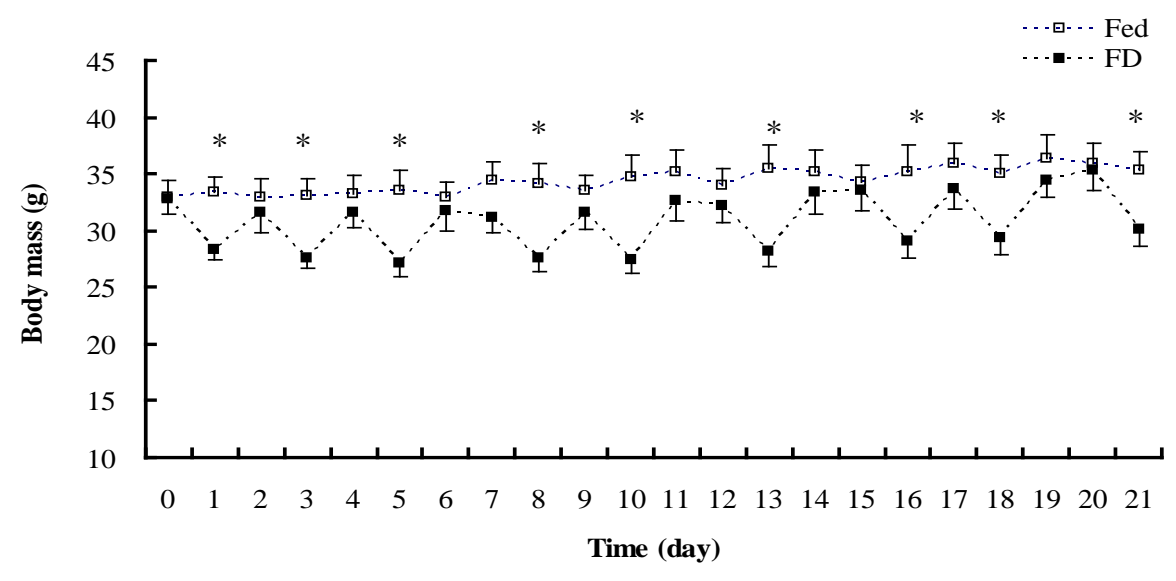

Figure 1. Changes of body mass in mice during stochastic food deprivation. Values are means \pm SE. Body mass on day 0 between the Fed and FD groups did not differ significantly, however body mass on stochastic days was much lower in the FD group than in the fed group. Note: $\square=$ Fed group, $\mathbf{\square}=$ FD group.

Body mass did not differ significantly between the two group on the other days.

\subsection{Body Composition}

Stochastic food deprivation significantly reduced wet carcass mass $(\mathrm{t}=2.169$, $\mathrm{df}=13, \mathrm{P}=0.049$ ), whereas other body composition and wet organ masses did not differ between the Fed and FD groups (Table 1, Table 2).

\subsection{White Blood Cells}

WBC was not influenced by stochastic food deprivation in mice $(\mathrm{t}=-0.005, \mathrm{df}=13, \mathrm{P}=0.996)$ (Figure 2).

\subsection{Cellular Immune Response}

PHA response was increased significantly in the FD group compared with the Fed group after $6 \mathrm{~h}(\mathrm{t}=-2.998$, $\mathrm{df}$ $=13, \mathrm{P}=0.010), 24 \mathrm{~h}(\mathrm{t}=-2.640, \mathrm{df}=13, \mathrm{P}=0.020)$ and $48 \mathrm{~h}(\mathrm{t}=-2.413, \mathrm{df}=13, \mathrm{P}=0.031)$ of PHA postimmunization (Figure 3).

\subsection{Serum Leptin Concentration}

Serum leptin concentration in the FD group was not different from the Fed group $(t=-1.588, \mathrm{df}=13, \mathrm{P}=0.136)$ (Figure 4). It was not correlated with total body fat mass $(\mathrm{r}=-0.469, \mathrm{P}=0.078)$, PHA response $(\mathrm{r}=-0.070, \mathrm{P}$ $=0.804)$ in both groups.

\subsection{Serum Corticosterone Concentration}

Corticosterone concentration was not affected by random food deprivation in mice $(\mathrm{t}=-1.954$, $\mathrm{df}=13, \mathrm{P}=$ 0.073) (Figure 5). It was not correlated with PHA response $(r=0.280, P=0.313)$ in both groups.

\section{Discussion}

Contrary to our expectation, we found that stochastic FD enhanced T cell-mediated immunity in Kunming mice. Immune organs and WBC were not affected by stochastic FD.

Adipose tissues are recently regarded as important endocrine and immune organs besides functioning as energy reserves [31] [32] [36] [37]. In addition to providing energy for costly physiological processes including immune responses, adipose tissues can secret some adipokines which are directly involved in immunity [38][40]. Houston et al. [41] have also shown that animals with low energy reserves would choose to allocate less energy to immune defense than animals with higher reserves. However, we found that stochastic FD had no significant effect on subcutaneus fat, perirenal fat, perigonadal fat, mesenteric fat and total body fat in FD mice. 
Table 1. Effect of stochastic food deprivation on body composition in mice.

\begin{tabular}{cccc}
\hline Parameters & Fed group & FD group & Statistical summary \\
\hline Sample size & 7 & 8 & $\mathrm{~ns}$ \\
Initial body mass (g) & $32.9 \pm 1.6$ & $32.9 \pm 1.4$ & $<0.05$ \\
Final body mass (g) & $35.4 \pm 1.6^{\mathrm{a}}$ & $30.1 \pm 1.5^{\mathrm{b}}$ & $<0.05$ \\
Wet carcass mass (g) & $24.7 \pm 1.3^{\mathrm{a}}$ & $21.0 \pm 1.1^{\mathrm{b}}$ & $\mathrm{ns}$ \\
Subcutaneus fat (g) & $0.32 \pm 0.07$ & $0.20 \pm 0.06$ & $\mathrm{~ns}$ \\
Subcutaneus fat content (\%) & $0.95 \pm 0.22$ & $0.63 \pm 0.19$ & $\mathrm{~ns}$ \\
Perirenal fat (g) & $0.13 \pm 0.02$ & $0.13 \pm 0.04$ & $\mathrm{~ns}$ \\
Perirenal fat content (\%) & $0.37 \pm 0.07$ & $0.41 \pm 0.12$ & $\mathrm{~ns}$ \\
Perigonadal fat (g) & $0.65 \pm 0.08$ & $0.52 \pm 0.14$ & $\mathrm{~ns}$ \\
Perigonadal fat content (\%) & $1.87 \pm 0.26$ & $1.64 \pm 0.39$ & $\mathrm{~ns}$ \\
Mesenteric fat (g) & $0.76 \pm 0.08$ & $0.53 \pm 0.11$ & $\mathrm{~ns}$ \\
Mesenteric fat content (\%) & $2.20 \pm 0.29$ & $1.69 \pm 0.28$ & $\mathrm{~ns}$ \\
Total body fat (g) & $1.86 \pm 0.18$ & $1.38 \pm 0.31$ & $\mathrm{~ns}$ \\
\hline Total body fat content (\%) & $5.40 \pm 0.67$ & $4.37 \pm 0.83$ & \\
\hline
\end{tabular}

Values are means \pm SE. Values for a specific parameter that share different superscripts are significantly different at $\mathrm{P}<0.05$, determined by independent-samples t-test. ns, not significant.

Table 2. Effect of stochastic food deprivation on wet organ mass in mice.

\begin{tabular}{|c|c|c|c|}
\hline Parameters & Fed group & FD group & Statistical summary \\
\hline Sample size & 7 & 8 & \\
\hline Heart (mg) & $170 \pm 15$ & $177 \pm 15$ & ns \\
\hline Lungs (mg) & $276 \pm 31$ & $293 \pm 31$ & ns \\
\hline Thymus (mg) & $34 \pm 8$ & $23 \pm 8$ & ns \\
\hline Liver (mg) & $1556 \pm 60$ & $1564 \pm 60$ & ns \\
\hline Spleen (mg) & $82 \pm 9$ & $82 \pm 9$ & ns \\
\hline Kidneys (mg) & $509 \pm 21$ & $515 \pm 21$ & ns \\
\hline Adrenal glands (mg) & $11 \pm 2$ & $9 \pm 2$ & ns \\
\hline Stomach with contents (mg) & $330 \pm 23$ & $345 \pm 23$ & ns \\
\hline Stomach (mg) & $222 \pm 15$ & $246 \pm 15$ & ns \\
\hline Small intestine with contents (mg) & $1917 \pm 134$ & $1942 \pm 134$ & ns \\
\hline Small intestine (mg) & $1242 \pm 144$ & $1264 \pm 144$ & ns \\
\hline Small intestine length $(\mathrm{cm})$ & $63.5 \pm 2.0$ & $68.6 \pm 2.0$ & ns \\
\hline Caecum with contents (mg) & $604 \pm 50$ & $491 \pm 50$ & ns \\
\hline Caecum (mg) & $165 \pm 22$ & $190 \pm 22$ & ns \\
\hline Caecum length (cm) & $3.4 \pm 0.3$ & $3.9 \pm 0.3$ & ns \\
\hline Colon with contents (mg) & $497 \pm 58$ & $479 \pm 58$ & ns \\
\hline Colon (mg) & $292 \pm 21$ & $317 \pm 21$ & ns \\
\hline Colon length (cm) & $9.9 \pm 0.6$ & $11.1 \pm 0.6$ & ns \\
\hline Total digestive tract (mg) & $1921 \pm 165$ & $2016 \pm 165$ & ns \\
\hline Total digestive tract length $(\mathrm{cm})$ & $76.7 \pm 2.2$ & $83.5 \pm 2.2$ & ns \\
\hline Testes $(\mathrm{mg})$ & $239 \pm 17$ & $260 \pm 17$ & ns \\
\hline Seminal vesical (mg) & $150 \pm 24$ & $130 \pm 24$ & ns \\
\hline
\end{tabular}

Values are means \pm SE. Values for a specific parameter that share different superscripts are significantly different at $\mathrm{P}<0.05$, determined by General Linear Model multivariate analysis followed by Bonferroni post hoc tests with body mass as the covariate ns, not significant. 


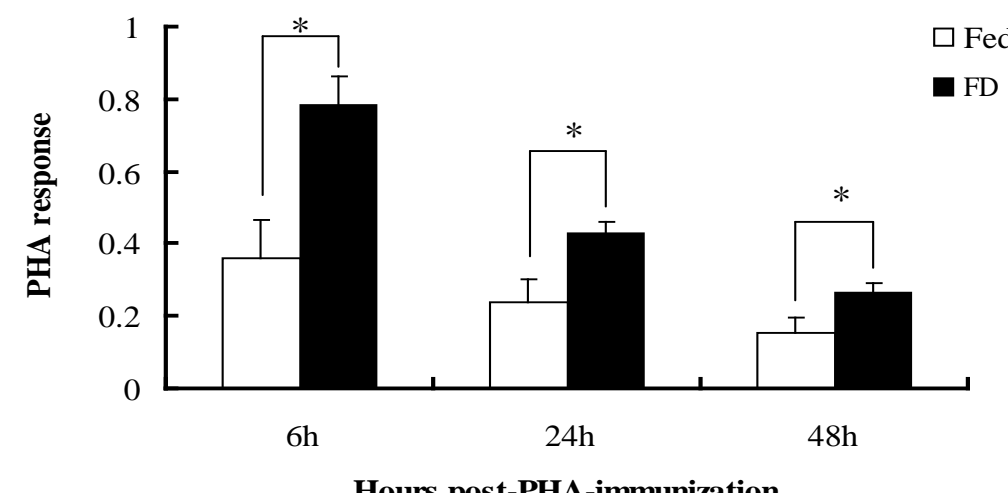

Hours post-PHA-immunization

Figure 2. Effect of stochastic food deprivation on PHA response in mice. Values are means \pm SE. PHA response was significantly higher in the FD group than in the Fed group. The white column represents the Fed group and solid column stands for the FD group. An asterisk $\left(^{*}\right)$ indicates statistical differences at $\mathrm{P}<0.05$.

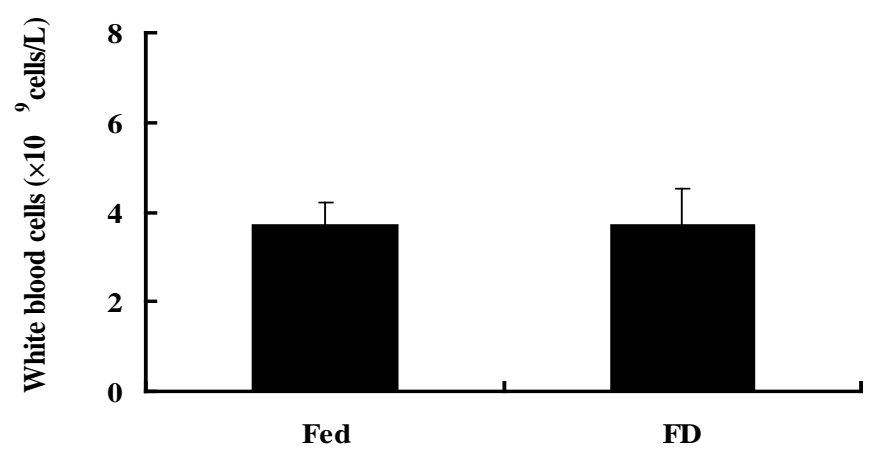

Figure 3. Effect of stochastic food deprivation on white blood cells in mice. Values are means \pm SE. WBC did not differ between the Fed and FD groups. The white column represents the Fed group and solid column stands for the FD group.

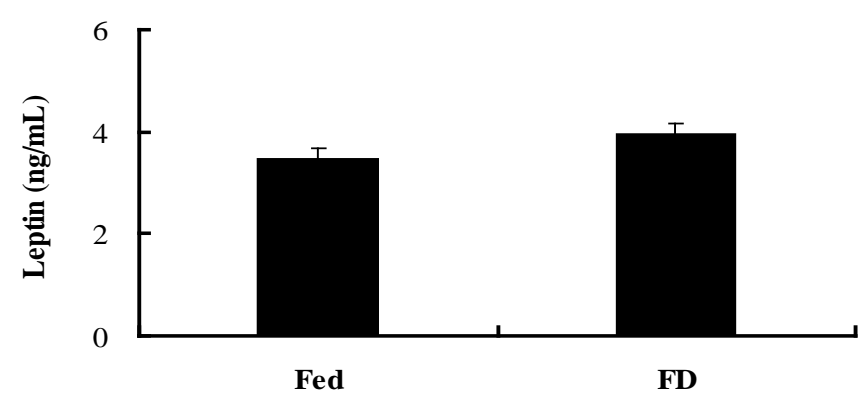

Figure 4. Effect of stochastic food deprivation on leptin concentration in mice. Values are means \pm SE. Serum leptin concentration was not different between the Fed and FD groups.

Changes of fat mass might not fully account for the improvement of cellular immunity in FD mice.

Leptin is mainly secreted by adipose tissues and plays an important role in immunity. It has recently been considered as a link between energy balance and immunity [42]. Leptin can protect mice from starvation-induced lymphoid atrophy and exogenous leptin administration can reverse starvation-induced immunosuppression in starved mice [43]. All these experiment indicated that lower leptin concentration can dampen immune responses [44]. In our study, leptin levels in the FD mice were not different from the fed controls, which implied that leptin might not contribute to the enhancement of cellular immunity in the FD mice. 


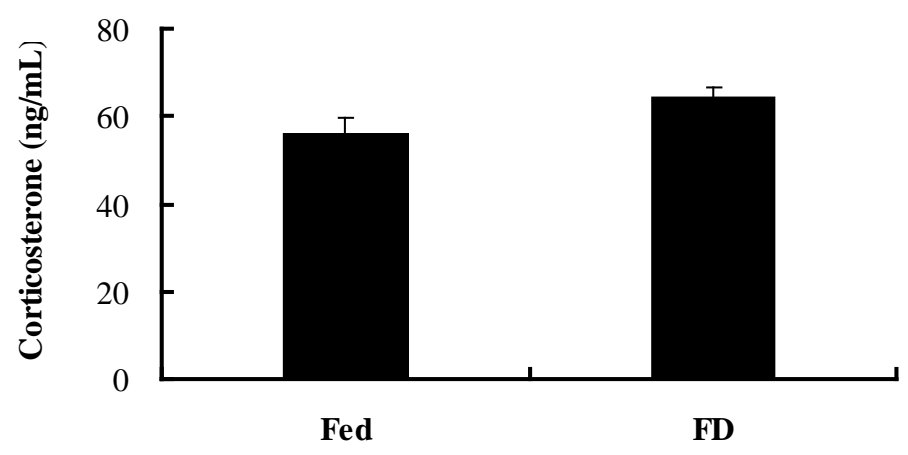

Figure 5. Effect of stochastic food deprivation on corticosterone concentration in mice. Values are means \pm SE. Serum corticosterone concentration was not different between the Fed and FD groups.

Stresses such as food deprivation generally activate the hypothalamic-pituitary-adrenal axis and promote secretion of glucocorticoids such as corticosterone. Corticosterone has been proved to have suppressive effect on immunity [15] [34]. In the present study, we found that corticosterone concentration was not responsive to stochastic FD in mice. These results showed that corticosterone might not explain the improvement of cellular immune responses in FD mice.

\section{Conclusion}

In conclusion, stochastic food deprivation can increase cellular immunity in FD mice, whereas it had no significant influence on other immune components such as thymus and spleen and white blood cells. Body fat mass, leptin and corticosterone concentrations did not respond to stochastic FD, which implied that they might not contribute to the enhancement of cellular immune responses in the FD mice. Further research is needed to clarify the improving effect of stochastic FD on Kunming mice.

\section{Acknowledgements}

The present study was supported by grants from the National Natural Science Foundation of China (No. 31370427), Natural Science Foundation of Shandong Province (ZR2013CM019), Crossing Research Project (71601) and the Doctor Initiation Foundation (bsqd20100204) to DLX.

\section{References}

[1] Sheldon, B.C. and Verhulst, S. (1996) Ecological Immunology: Costly Parasite Defences and Trade-Offs in Evolutionary Ecology. Trends in Ecology and Evolution, 11, 317-321. http://dx.doi.org/10.1016/0169-5347(96)10039-2

[2] Owens, I.P.F. and Wilson, K. (1999) Immunocompetence: A Neglected Life History Trait or Conspicuous Red Herring? Trends in Ecology and Evolution, 14, 170-172. http://dx.doi.org/10.1016/S0169-5347(98)01580-8

[3] Nelson, R.J. and Demas, G.E. (1996) Seasonal Changes in Immune Function. Quarterly Review of Biology, 71, 512548. http://dx.doi.org/10.1086/419555

[4] Martin, L.B., Weil, Z.M. and Nelson, R.J. (2008) Seasonal Changes in Vertebrate Immune Activity: Mediation by Physiological Trade-Offs. Philosophical Transactions of the Royal Society B: Biological Sciences, 363, 321-339. http://dx.doi.org/10.1098/rstb.2007.2142

[5] Chandra, R.K. (1996) Nutrition, Immunity and Infection: From Basic Knowledge of Dietary Manipulation of Immune Responses to Practical Application of Ameliorating Suffering and Improving Survival. Proceedings of the National Academy of Sciences of the United States of America, 93, 14304-14307. http://dx.doi.org/10.1073/pnas.93.25.14304

[6] Calder, P.C. and Kew, S. (2002) The Immune System: A Target for Functional Foods? British Journal of Nutrition, 88, S165-S176. http://dx.doi.org/10.1079/BJN2002682

[7] Kaminogawa, S. and Nanno, M. (2004) Modulation of Immune Functions by Foods. Evidence-Based Complementary and Alternative Medicine, 1, 241-250. http://dx.doi.org/10.1093/ecam/neh042

[8] Schaible, U.E. and Kaufmann, S.H.E. (2007) Malnutrition and Infection: Complex Mechanisms and Global Impacts. Plos Medicine, 4, 806-812. http://dx.doi.org/10.1371/journal.pmed.0040115 
[9] Lord, G.M., Matarese, G., Howard, J.K., Baker, R.J., Bloom, S.R. and Lechler, R.I. (1998) Leptin Modulates the T-Cell Immune Response and Reverses Starvation-Induced Immunosuppression. Nature, 394, 897-901. http://dx.doi.org/10.1038/29795

[10] Nohr, C.W., Tchervenkov, J.I., Meakins, J.L. and Christou, N.V. (1985) Malnutrition and Humoral Immunity: Short Term Acute Nutritional Deprivation. Surgery, 98, 769-775.

[11] Nakamura, H., Kouda, K., Fan, W.Y., Watanabe, T. and Takeuchi, H. (2001) Suppressive Effects on Allergic Contact Dermatitis by Short-Term Fasting. Toxicological Pathology, 29, 200-207. http://dx.doi.org/10.1080/019262301317052477

[12] Nakamura, H., Koud, K., Tokunaga, R. and Takeuchi, H. (2004) Suppressive Effects on Delayed Type Hypersensitivity by Fasting and Dietary Restriction in ICR Mice. Toxicological Letters, 146, 259-267. http://dx.doi.org/10.1016/j.toxlet.2003.10.008

[13] Faggioni, R., Moser, A., Feingold, K.R. and Grunfeld, C. (2000) Reduced Leptin Levels in Starvation Increase Susceptibility to Endotoxic Shock. American Journal of Pathology, 156, 1781-1787. http://dx.doi.org/10.1016/S0002-9440(10)65049-3

[14] Kohno, H., Kouda, K., Ishihara, H., Nishio, N., Sasaki, Yu., Nakamura, H., Iki, M. and Sonoda, Y. (2011) Intermittent Fasting Ameliorates Delayed-Type Hypersensitivity in NC/Nga Mice. Food and Nutrition Sciences, 2, 287-293. http://dx.doi.org/10.4236/fns.2011.24041

[15] Xu, D.L. and Wang, D.H. (2010) Fasting Suppresses T Cell-Mediated Immunity in Female Mongolian Gerbils (Meriones unguiculatus). Comparative and Biochemical Physiology Part A, 155, 25-33. http://dx.doi.org/10.1016/j.cbpa.2009.09.003

[16] Wing, E.J. and Young, J.B. (1980) Acute Starvation Protects Mice against Listeria monocytogenes. Infectious Immunology, 28, 771-776.

[17] Kubo, C., Teshima, H. and Ago, Y. (1982) The Effects of Acute Starvation on the Function of Immune System. Japanese Journal Psychosomal Medicine, 22, 249-254.

[18] Wing, E.D., Stanko, R.T., Winkelstein, A. and Adibi, S.A. (1983) Fasting Enhanced Immune Effector Mechanisms in Obese Subjects. The American Journal of Medicine, 75, 91-96. http://dx.doi.org/10.1016/0002-9343(83)91172-5

[19] Hayati, F., Maleki, M., Pourmohammad, M., Sardari, K., Mohri, M. and Afkhami, A. (2011) Influence of Short-Term, Repeated Fasting on the Skin Wound Healing of Female Mice. Wounds, 23, 38-43.

[20] Sogawa, H. and Kubo, C. (2000) Influence of Short-Term Repeated Fasting on the Longevity of Female (NZB $\times$ NZW) F1 Mice. Mechanism Ageing Development, 115, 61-71. http://dx.doi.org/10.1016/S0047-6374(00)00109-3

[21] Smits, J.E., Bortolotti, G.R. and Tella, J.L. (1999) Simplifying the Phytohaemagglutinin Skin-Testing Technique in Studies of Avian Immunocompetence. Functional Ecology, 13, 567-572. http://dx.doi.org/10.1046/j.1365-2435.1999.00338.x

[22] de Bellocq, J.G., Krasnov, B.R., Khokhlova, I.S. and Pinshow, B. (2006) Temporal Dynamics of a T-Cell Mediated Immune Response in Desert Rodents. Comparative and Biochemical Physiology Part A: Molecular \& Integrative Physiology, 145, 554-559. http://dx.doi.org/10.1016/j.cbpa.2006.08.045

[23] Savino, W. and Dardenne, M. (2000) Neuroendocrine Control of Thymus Physiology. Endocrine Review, 21, $412-443$.

[24] Smith, K.G. and Hunt, J.L. (2004) On the Use of Spleen Mass as a Measure of Avian Immune System Strength. Oecologia, 138, 28-31. http://dx.doi.org/10.1007/s00442-003-1409-y

[25] Artacho, P., Soto-Gamboa, M., Verdugo, C. and Nespolo, R.F. (2007) Using Haematological Parameters to Infer the Health and Nutritional Status of an Endangered Black-Necked Swan Population. Comparative and Biochemical Physiology Part A: Molecular \& Integrative Physiology, 147, 1060-1066. http://dx.doi.org/10.1016/j.cbpa.2007.03.017

[26] Zhang, Y.Y., Proenca, R., Maffei, M., Barone, M., Leopold, L. and Friedman, J.M. (1994) Positional Cloning of the Mouse Obese Gene and Its Human Homologue. Nature, 372, 425-432. http://dx.doi.org/10.1038/372425a0

[27] Faggioni, R., Feingold, K.R. and Grunfeld, C. (2001) Leptin Regulation of the Immune Response and the Immunodeficiency of Malnutrition. The FASEB Journal, 15, 2565-2571. http://dx.doi.org/10.1096/fj.01-0431rev

[28] Schäffler, A., Schölmerich, J. and Salzberger, B. (2007) Adipose Tissue as an Immunological Organ: Toll-Like Receptors, C1q/TNFs and CTRPs. Trends in Immunology, 28, 393-399. http://dx.doi.org/10.1016/j.it.2007.07.003

[29] Matarese, G., Moschos, S. and Mantzoros, C.S. (2005) Leptin in Immunology. Journal of Immunology, 174, 31373142. http://dx.doi.org/10.4049/jimmunol.174.6.3137

[30] Lam, Q.L.K. and Lu, L.W. (2007) Role of Leptin in Immunity. Cellular and Molecular Immunology, 4, 1-13.

[31] Ahima, R.S. and Flier, J.S. (2000) Adipose Tissue as an Endocrine Organ. Trends in Endocrinology and Metabolism, 11, 327-332. http://dx.doi.org/10.1016/S1043-2760(00)00301-5 
[32] Fantuzzi, G. (2005) Adipose Tissue, Adipokines, and Inflammation. The Journal of Allergy and Clinical Immunology, 115, 911-919. http://dx.doi.org/10.1016/j.jaci.2005.02.023

[33] Ahima, R.S., Prabakaran, D., Mantzoros, C., Qu, D.Q., Lowell, B., Maratos-Flier, E. and Flier, J.S. (1996) Role of Leptin in the Neruoendocrine Response to Fasting. Nature, 382, 250-252. http://dx.doi.org/10.1038/382250a0

[34] Sapolsky, R.M., Romero, L.M. and Munck, A.U. (2000) How Do Glucocorticoids Influence Stress Responses? Integrating Permissive, Suppressive, Stimulatory, and Preparative Actions. Endocrine Review, 21, 55-89.

[35] Yang, X.P. (2004) Laboratory Manual in Animal Physiology. Higher Education Press, Beijing, 91-94.

[36] Matarese, G. and Cava, A.L. (2004) The Intricate Interface between Immune System and Metabolism. Trends in Immunology, 25, 193-200. http://dx.doi.org/10.1016/j.it.2004.02.009

[37] Trayhurn, P. (2005) Endocrine and Signalling Role of Adipose Tissue: New Perspectives on Fat. Acta Physioliguca Scandinavica, 184, 285-293. http://dx.doi.org/10.1111/j.1365-201X.2005.01468.x

[38] Moret, Y. and Schmid-Hempel, P. (2000) Survival for Immunity: The Price of Immune System Activation for Bumblebee Workers. Science, 290, 1166-1168. http://dx.doi.org/10.1126/science.290.5494.1166

[39] Demas, G.E. (2004) The Energetics of Immunity: A Neuroendocrine Link between Energy Balance and Immune Function. Hormone and Behavior, 45, 173-180. http://dx.doi.org/10.1016/j.yhbeh.2003.11.002

[40] Lago, F., Dieguez, C., Gómez-Reino, J. and Gualillo, O. (2007) Adipokines as Emerging Mediators of Immune Response and Inflammation. Nature Clinical Practice Rheumatology, 3, 716-724. http://dx.doi.org/10.1038/ncprheum0674

[41] Houston, A.I., McNamara, J.M., Barta, Z. and Klasing, K.C. (2007) The Effect of Energy Reserves and Food Availability on Optimal Immune Defence. Proceedings of the Royal Society B, 274, 2835-2842. http://dx.doi.org/10.1098/rspb.2007.0934

[42] Steiner, A.A. and Romanovsky, A.A. (2007) Leptin: At the Crossroads of Energy Balance and Systemic Inflammation. Progress in Lipid Research, 46, 89-107. http://dx.doi.org/10.1016/j.plipres.2006.11.001

[43] Howard, J.K., Lord, G.M., Matarese, G., Vendetti, S., Ghatei, M.A., Ritter, M.A., Lechler, R.I. and Bloom, S.R. (1999) Leptin Protects Mice from Starvation-Induced Lymphoid Atrophy and Increases Thymic Cellularity in ob/ob Mice. Journal of Clinical Investment, 104, 1051-1059. http://dx.doi.org/10.1172/JCI6762

[44] Flier, J.S. (1998) Lowered Leptin Slims Immune Response. Nature Medicine, 4, 1124-1125. http://dx.doi.org/10.1038/2619 